\title{
Методика выявления и разрешения градостроительных конфликтов и противоречий развития на уровне муниципального района
}

\author{
М.В.Перькова, БГТУ им. Шухова, Белгород
}

В исследовании предлагается к развитию конфликтологический подход для достижения целей устойчивого развития, повышения эффективности территориального планирования и управления территорией региональной системы расселения в условиях рыночных отношений. Разработана методика выявления и разрешения градостроительных конфликтов и противоречий развития на уровне муниципального района. Она включает четыре этапа: 1) периодизацию пространственного освоения территории в исторической ретроспективе как результат возникающих и эволюционирующих конфликтов, повлёкших градостроительные противоречия развития на территории; 2) качественную и количественную оценку ресурсного потенциала территории; 3) выявление и классификацию градостроительных конфликтов и противоречий развития территории; 4) применение существующих и разработку новых методов разрешения конфликтов интересов и ценностей с целью моделирования различных вариантов землепользования.

Разработанная методика апробирована на примере муниципальных районов Белгородской области. Изучены особенности административно-территориального деления Белгородского края, которые характеризуют устойчивые во времени территориальные единицы с различными видами народнохозяйственной деятельности. Осуществлена индикативная интегральная оценка ресурсного потенциала территории и топологический анализ муниципальных районов Белгородской области и выявлены исторические, пространственные и функциональные закономерности, а также градостроительные конфликты и противоречия, возникающие в процессе освоения территории в XXI веке. Проведена интегральная оценка ресурсного потенциала территории муниципальных районов Белгородской области и выявлены градостроительные противоречия развития территории в XXI веке. Для разрешения градостроительных конфликтов и противоречий развития на уровне муниципального района предложены усовершенствованные методы: метод разрешения социальноинфраструктурных противоречий развития территории; метод формирования восстановительного рельефа нарушенных территорий; метод формирования природного ядра на основе овражно-балочных ландшафтов, - и апробированы на территориях Белгородского, Шебекинского и Яковлевского муниципальных районах. Разработан и апробирован метод гармонизации интересов и ценностей путём поиска компромисса между участниками градостроительной деятельности для территорий с различной функциональной нагрузкой на примере разработки концепции градостроительного разви- тия межмуниципального природного парка на территории Белгородского и Шебекинского районов ${ }^{1}$.

Ключевые слова: региональная система расселения, муниципальный район, градостроительные конфликты и противоречия, методика.

The Methods of Identification and Resolution of Urban Conflicts and Contradictions of Development at the Level of Municipal Area

M.V.Perkova, BSTU, Belgorod

The study proposes to develop a conflictological approach for achieving the goals of sustainable development, increasing the efficiency of territorial planning and managing the territory of the regional settlement system in a market economy. A methodology for identifying and resolving urban conflicts and developmental contradictions at thelevel of a municipal district has been developed. It includes 4 stages: 1 ) the periodization of the spatial development of the territory in historical retrospect as a result of emerging and evolving conflicts, which resulted in urban development contradictions in the territory; 2) qualitative and quantitative assessment of the resource potential of the territory; 3 ) identification and classification of urban conflicts and contradictions in the development of the territory; 4) the application of existing and the development of new methods for resolving conflicts of interests and values with a view to modeling various options forland use.

The developed methodology is tested on the example of municipal districts of the Belgorod region. Peculiarities of the administrative-territorial division of the Belgorod region, which characterize the time-stable territorial units with various types of economic activity are studied. An indicative integrated assessment of the resource potential of the territory and topological analysis of the municipal districts of the Belgorod region were carried out and historical, spatial and functional patterns, as well as urban conflicts and contradictions in the process of developing the territory in the XXI century were revealed. An integral assessment of the resource potential of the municipal districts territory of the Belgorod region was carried out and urban development contradictions in the development of the territory in the XXI century were identified. To resolve urban conflicts and contradictions of development at thelevel of the municipal district, improved methods are proposed: the method of

${ }_{1}^{1}$ Работа подготовлена в рамках Программы развития опорного университета на базе БГТУ им. В.Г. Шухова. 
resolving social and infrastructure contradictions of the territory development; the method of formation of the rehabilitative relief of disturbed territories; the method of formation of the natural core on the basis of ravine-beamlandscapes, and they were tested in the territories of the Belgorod Shebekinsky and Yakovlevsky municipal districts. The method of harmonization of interests and values was developed and tested by finding a compromise between the participants of urban development for areas with different functionalload on the example of the concept of urban development of intermunicipal natural Park in the Belgorod and Shebekinsky districts.

Keywords: regional settlement system, municipal district, urban planning conflicts and contradictions, methodology.

В настоящее время возникла объективная необходимость В развитии подхода, связанного с решением проблем градостроительных конфликтов и противоречий развития территории. В результате активной индустриализации и бурного роста городов, начиная c середины XIX века, происходит сокращение роли природного каркаса и, как следствие, утрата экологической устойчивости на планете. Противоречивость развития в градостроительстве заключается, с одной стороны, в обеспечении качественных комфортных условий для жизнедеятельности и использовании ресурсного потенциала территории, с другой - в потере природного и историко-культурного своеобразия территории. Исследования, так или иначе затрагивающие городские конфликты, можно найти в работах В. Глазычева, Л. Когана, А. Крашенинникова, Е. Ещиной, Е.О. Фрейдина, А. В. Нефедова, Т. Дридзе, Л. Цой, К. Линча, Д. Форрестера, С. Боэри, Г. Эдельмана, Б. де Мелдера, Л. Вирта, Э. Берджесса, М. Кастельса, Г. Эдельмана и др. А.Г. Большаков разработал модель управления конфликтами в использовании территории с целью её устойчивого развития [2]. Ю.М. Моисеев описывал конфликты в контексте градостроительного развития [8], Д.М. Хомяков изучал противоречия развития загородных поселений Московского региона и описывал конфликты формирования субурбий [13]. Чернова Е.Б. рассматривает противоречие социальных и экономических целей [16], обосновывает использование проблемно-конфликтного подхода и раскрывает методологические и практические аспекты социологического обоснования при разработке стратегий территориального развития [15]. В связи с актуальностью вопроса разрешения конфликтов и противоречий развития в градостроительной деятельности предлагается обобщить исследования и предложить к развитию конфликтологический подход в градостроительстве.

Цели градостроительного развития города должны учитывать государственные, общественные и частные интересы и быть направлены на рациональное природопользование и сохранение историко-культурного наследия. В больших и малых городах как РФ, так и зарубежных стран неизбежны противоречия при строительстве новых объектов, реконструкции территории, развитии инженерной и транспортной инфраструктуры и решении вопросов охраны окружающей среды, защиты природного каркаса, охраны историко-культурного наследия, а также обеспечении комфортной среды жизнедеятельности населённых пунктов.

В связи с вышесказанным, автором предлагается развитие конфликтологического подхода в теории, методологии и практике градостроительной деятельности, который предполагает механизм разрешения градостроительных противоречий путем выявления, классификации и разрешения градостроительных конфликтов для достижения целей устойчивого развития, повышения эффективности территориального планирования и управления территорией региональной системы расселения в условиях рыночных отношений [11].

В рамках разрабатываемого подхода сформулированы основные принципы градостроительного развития региональной системы расселения.

1. Принцип территориальной обусловленности раскрывает зависимость состава и качественного выражения региональных особенностей.

2. Принцип градостроительной интеграции и ландшафтосообразности раскрывает зависимость развития территории от природных и историко-культурных факторов.

3. Принцип преемственности раскрывает функционально-структурное соответствие и архитектурно-планировочное обеспечение выполнения актуальных задач проектирования в региональном контексте. Предполагает использование традиционных для региона схем функциональной и планировочной организации, присущих региональным историческим, национальным типам зданий и сооружений, а также пространственной организации территории.

4. Принцип сохранения идентичности направлен на выявление природного и историко-культурного своеобразия населённых мест.

5. Принцип разрешения градостроительных противоречий реализуется путём гармонизации частных, общественных интересов и интересов природного каркаса и применяется путём разрешения конфликтов интересов, ценностей и пространственных структур.

Проблемы развития территории обусловлены возникающими противоречиями между участниками градостроительной деятельности. Как результат может возникнуть конфликт при решении сложившейся проблемы по отношению к территории. Понятийный аппарат основывается на представлении, что конфликт функции возникает, если на одну и ту же территорию претендуют различные социальные группы с противоположными интересами, потребностями и мотивациями. В исследовании предложено определение градостроительного конфликта - это столкновение противоположных интересов и потребностей участников градостроительной деятельности по отношению к территории.

Если конфликт решен в пользу конкретных лиц, лоббировавших свои личные интересы не в пользу устойчивого развития территории, то через определённый интервал вре- 
мени проявятся последствия неверных решений, названные градостроительным противоречием развития территорий.

Подразумевается, что градостроительное противоречие развития территории - ситуация, при которой в процессе землепользования резко снижается качество искусственно-естественной среды региона. В градостроительстве при одновременной истинности двухвзаимоисключающих вариантов землепользования приоритет должен быть отдан сохранению природного каркаса.

В исследовании разработана комплексная многоуровневая методическая последовательность градостроительного регулирования с целью выявления, разрешения и прогнозирования градостроительных конфликтов на региональном, муниципальном и местном уровнях. Она может применяться как при разработке стратегии пространственного развития - концептуальной части территориального планирования, последовательности и направленности освоения пространства [6], так и учитываться в документах территориального планирования и градостроительного зонирования [7]. Методика выявления, разрешения и прогнозирования градостроительных конфликтов на региональном уровне в рамках развиваемого подхода была ранее опубликована [11]. В данной статье рассматривается муниципальный уровень (рис. 1). Необходимо отметить, что в 1979 году ЦНИИП градостроительства под руководством В.В. Владимирова было разработано «Руководство, по комплексной оценке, и функциональному зонированию в районной планировке», которое было в дальнейшем доработано и издано в 1982 году. Целью оценки было определение эффективного функционального использования территории. В Руководстве использовался показатель демографической ёмкости территории, его сопоставление с фактическими данными, степень превышения допустимых нагрузок и ограничительные критерии при проектировании перспективного использования территории. Однако возникновение правового градорегулирования в условиях рыночных отношений, наличие градостроительного зонирования (правил землепользования и застройки) требует дополнения к существующим комплексным оценкам с целью выявления существующих и прогнозирования потенциальных конфликтов участников градостроительной деятельности по отношению к территории.

Разработанная методика апробирована на примере муниципальных районов Белгородской области. Она включает четыре этапа (см. рис. 1).

1 этап. Периодизация пространственного освоения территории в исторической ретроспективе как результат возникающих и эволюционирующих конфликтов, повлёкших градостроительные противоречия развития на территории. На муниципальном уровне предполагается изучение особенностей административно-территориального деления территории с целью выявления устойчивых единиц и характера освоения территории.

2 этап. Качественная и количественная оченка ресурсного потенциала территории. Выявление особенностей освоения территории и характеристика качества среды жизнедеятельности на современном этапе развития. Решение задач устойчивого развития России с использованием базовой системы индикаторов оценки на сегодняшний день является актуальной [4]. Количественная оценка ресурсного потенциала территории в данном исследовании также основана на индикативном планировании и предполагает следующую последовательность:

1) формирование перечня индикаторов по группам ресурсного потенциала (природный, историко-культурный, туристско-рекреационный, туристско-инфраструктурный, транспортно-инфраструктурный, экономический);

2) интегральную оценку индикаторов по каждой группе, основанную на методе сравнительного анализа;

3) выявление особенностей градостроительного развития территории;

4) ранжирование муниципальных районов по видам ресурсного потенциала.

Далее осуществляется изучение топологических характеристик транспортной сети муниципальных районов:

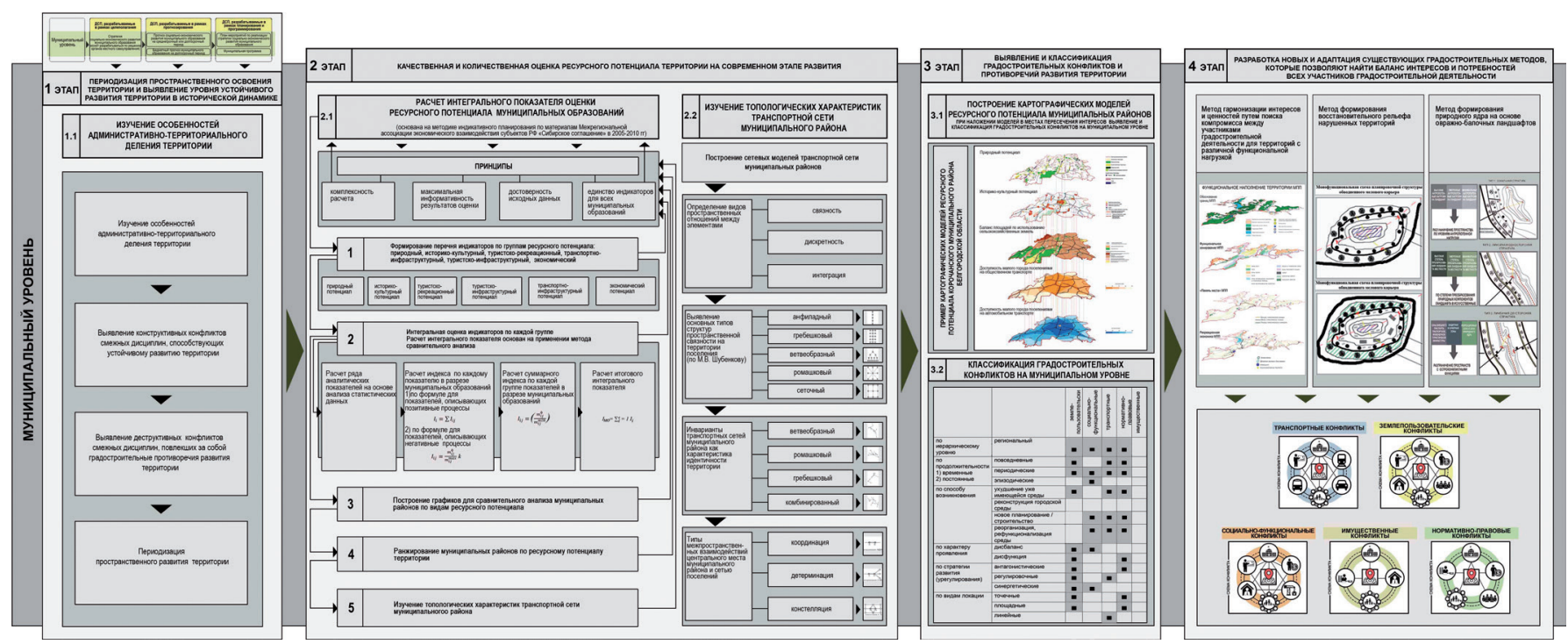

Рис. 1. Методика выявления, разрешения и прогнозирования градостроительных конфликтов на муниципальном уровне 
1) построение сетевых моделей транспортной сети;

2) определение видов пространственных отношений между элементами;

3) выявление основных типов пространственных структур по связности как инвариантов транспортных сетей муниципального района и населённых пунктов;

4) характеристика межпространственных взаимодействий между центральным местом и сетью поселений [14].

3 этап. Выявление и классификация градостроительных конфликтов и противоречий развития территории.

Построение пространственных моделей ресурсного потенциала территории (природный, историко-культурный, сельскохозяйственный потенциал земель, экономический, зоны доступности центра муниципального района на личном и общественном транспорте) и их наложение друг на друга позволяет определить места пересечения интересов, выявить и классифицировать градостроительные конфликты на муниципальном уровне.

С целью изучения транспортного каркаса территории муниципальных районов были разработаны методы, позволяющие оценить доступность центрального места - малого города, для жителей населённых пунктов района. При построении зон доступности используются топографические карты уровня территориального планирования муниципального района, на которых отображены дороги регионального и местного уровней, а также местные проезды, карты Google Maps (карты Google), программы-приложения.

Метод определения зон доступности общественным транспортом центрального места. Осуществляется построение сети дорог, по которым движется общественный транспорт, связывающий населённые пункты с центром муниципального образования - малым городом. Для расчёта используется программа-приложение спутниковой системы «Navitel», рассчитывается скорость движения общественного транспорта с учётом ограничений правил дорожного движения для непикового времени суток весенне-летнего периода. При этом необходимо ввести коэффициент $K_{\text {от' }}$ учитывающий интервалы движения маршрутных автобусов и отражающий величину интервалов в расписании движения общественного транспорта. Составляется таблица по времени доступности каждого населённого пункта. Поселения классифицируются по уровню доступности. На карту-схему наносятся точки согласно уровням доступности населённого пункта и соединяются, образуя зоны доступности.

Метод определения зон доступности личным транспортом центрального места. Последовательность такая же, только рассчитывается скорость движение личного транспорта с учетом ограничений ПдД для весенне-летнего периода непикового времени суток.

4 этап. Применение существующих и разработка новых методов разрешения конфликтов интересов и ценностей с целью моделирования различных вариантов землепользования. Усовершенствованы методы градостроительного проектирования с учётом разрешения градостроительных конфликтов и противоречий развития территории муниципальных районов: метод разрешения социально-инфраструктурных противоречий развития территории; метод формирования восстановительного рельефа нарушенных территорий; метод формирования природного ядра на основе овражно-балочных ландшафтов. Разработан и апробирован метод гармонизации интересов и ценностей путем поиска компромисса между участниками градостроительной деятельности для территорий с различной функциональной нагрузкой на примере разработки «Концепции градостроительного развития межмуниципального природного парка на территории Белгородского и Шебекинского районов».

Разработанная методика апробирована на примере оценки территории муниципальных районах Белгородской области. На первом этапе исследования выявлено, что административно-территориальное деление нашего края в целом соответствует преобразованиям, проводимым в нашей стране, хотя изменения, связанные с местными ситуациями, характерными только для изучаемой территории, также имели место. Административно-территориальное деление Белгородчины можно разделить на четыре периода:

1) начальный период (с XVI века по 1917 год);

2) административно-территориальное деление до образования Белгородской области (1917-1953);

3) административно-территориальное деление с 1954-го по 2008 год;

4) современное административно-территориальное деление территории (2009-2018).

Первый период. В конце XVI - первой половине XVII века в российском государстве исторически сложились территориальные единицы, названия которых не были официально узаконены. Первоначально существовало территориальное деление: уезды - станы - деревня - село - починки. Пространства, занятые уездами, были очень большие по территории. Каждому городу отводилась своя территория, составлявшая его уезд. Территории уездов складывались исторически, чётко определённых границ в начале XVII века не было. Для управления уездами в XVII веке в России была принята воеводская форма правления. Образован Белгородский разряд с центром в городе Белгороде в 1658 году. Он располагался на территории современных Орловской, Курской, Белгородской, Сумской, Харьковской и Воронежской областей.

В результате реформы Петра I территориальное деление России меняется, уезды объединяются в провинции: губерния - провинция (ландратские доли) - дискринт. Белгородская провинция входит в состав Киевской губернии. В 1775 году Россия поделена на 50 губерний и Белгородская губерния вновь выделена в самостоятельную со следующим территориальным делением: губерния - уезд - город (как самостоятельная единица). В состав Белгородской провинции входили 20 городов с уездами [1]. С 1778 года Белгородская губерния упразднена, территории разделены между Курской губернией и Воронежским наместничеством. В этот период на «... развитие архитектуры и территориального устройства юга России», согласно исследованиям Г.В. Есаулова, оказывают влияние «главные природные пространственные свойства региона: «пограничность», «периферийность», «проницаемость» и «локальная замкнутость», 
которые «...определили своеобразие исторического пути формирования архитектурных культур» [3]. Проходившие в этот период военные действия способствовали освоению южного порубежья России, и Белгородская черта явилась прямой пространственно-исторической предшественницей Белгородской региональной системы расселения. В это время большинство городов-крепостей получили свое развитие как центральные места локальных систем расселения.

Второй период. В 1917 году территориальное деление России происходило по принципу: губерния - уезд - волость - село. В 1924 году в СССР вместо губерний и уездов территория была разделена на округа - районы - города - сельсоветы, в 1928-ом в России была введена новая единица административно-территориального деления - область. Центрально-Чернозёмная область включала 11 округов, в том числе Белгородский. В 1934 году Центрально-Чернозёмная область была разделена, и часть территорий отошли Воронежской, а часть - Курской областям [1]. Во время второго периода происходило активное освоение территории под сельскохозяйственное использование. Это послужило возникновению конфликта экономики и экологии, способствовало резкому снижению облесенности и обводнённости территории. Также за рассматриваемый период в результате военных действий было утеряно много объектов историко-культурного наследия.

Третий период. В 1954 году была образована Белгородская область. В 1954-1991 годы происходило образование, восстановление, укрупнение и переименование районов Белгородской области. В результате народнохозяйственной деятельности имело место необоснованное разрушение объектов историко-культурного наследия. Например, снос остатков Белгородской крепости с целью освоения запасов мела и строительства промышленного объекта. В целом во время третьего периода происходило активное освоение минерально-сырьевой базы на территории, что обострило конфликт экономики и экологии и привело к формированию техногенных ландшафтов.

Четвёртый период. В 2008 году сложилась система административно-территориального деления, которая сохраняется по настоящее время. На сегодняшний день Белгородская область включает 19 муниципальных районов, 3 городских округа, 25 городских и 260 сельских поселений [1].

Социально-экономические конфликты, имевшие место на территории всей страны в последнее десятилетие XX и первое десятилетие XXI веков, повлекли за собой возникновение градостроительных противоречий развития локальных и региональных систем расселения. На территории нашего региона они разрешались следующим образом:

1) произошли структурные изменения в управлении развитием территории, связанные с социально-экономическим реформированием регионального агропромышленного комплекса;

2) начали активно формироваться субурбии в пригородах в связи со строительством микрорайонов с индивидуальной жилой застройкой;
3) на границе крупных городов и их пригородов начали строиться промышленные парки;

4) произошёл переход от ситуативного управления на новую проектную управленческую модель с целью создания конкурентоспособной парадигмы социально-экономического развития.

Однако необходимо отметить, что конфликты землепользования разрешаются на данном этапе административными методами управления территорией путем поиска компромисса в пользу социально-экономического развития территории.

На сегодняшний день в регионе наблюдается двуядерная структура, включающая Белгородскую и Губкинстко-Старооскольскую агломерированные территории. Анализируя политико-административную ситуацию в настоящее время, можно сделать вывод, что в результате сложившейся геополитической ситуации с Украиной Белгород как областной центр на сегодняшний день является тупиковым городом а изучение отраслевой специализации территории показывает, что на протяжении изучаемого периода экономическое районирование, хотя и имело свою специфику, было связано с административным. Развитие производства регионального значения (завод «Энергомаш», витаминный комбинат и пр.) в советский период происходило в областном центре и ближайшем к нему малом городе Шебекино. Моногорода как таковые в области отсутствуют, исторически формировалась многофункциональная структура экономики. Исключение составляет средний город Губкин, градообразующая база которого основана на освоении железорудных запасов. В результате изучения ресурсного потенциала территории выявлены районы, ориентированные на добычу полезных ископаемых (Губкинский, Старооскольский, Яковлевский), туризм, рекреацию (Шебекинский, Грайворонский), формирование военной базы (Валуйский).

На втором этапе исследования была проведена качественная и количественная оценка муниципальных районов Белгородской области и выявлено следующее:

1) природный каркас всех муниципальных районов, за исключением Шебекинского, имеет минимальный набор компонентов для устойчивого развития. Необходимо формирование ядер природноэкологического каркаса на базе байрачных ${ }^{2}$ лесов и оврагов [9];

2) историко-культурное наследие муниципальных районов представлено малоизученными объектами археологического наследия (50\%); памятниками архитектуры (16,3\%); памятниками садово-паркового искусства (0,5\%) и памятниками воинской славы Великой Отечественной войны 1941-1945 годов (33,2\%) (рис. 2);

3) в муниципальных районах формируются различные виды туризма: сельский туризм (Алексеевский), культурнопознавательный туризм (Грайворонский, Валуйский), рекреационный туризм (Шебекинский, Валуйский, Корочанский), событийный туризм (Грайворонский, Корочанский) [10];

4) доступность центрального места в локальных системах расселения характеризуется частично замкнутой дорожной сетью 


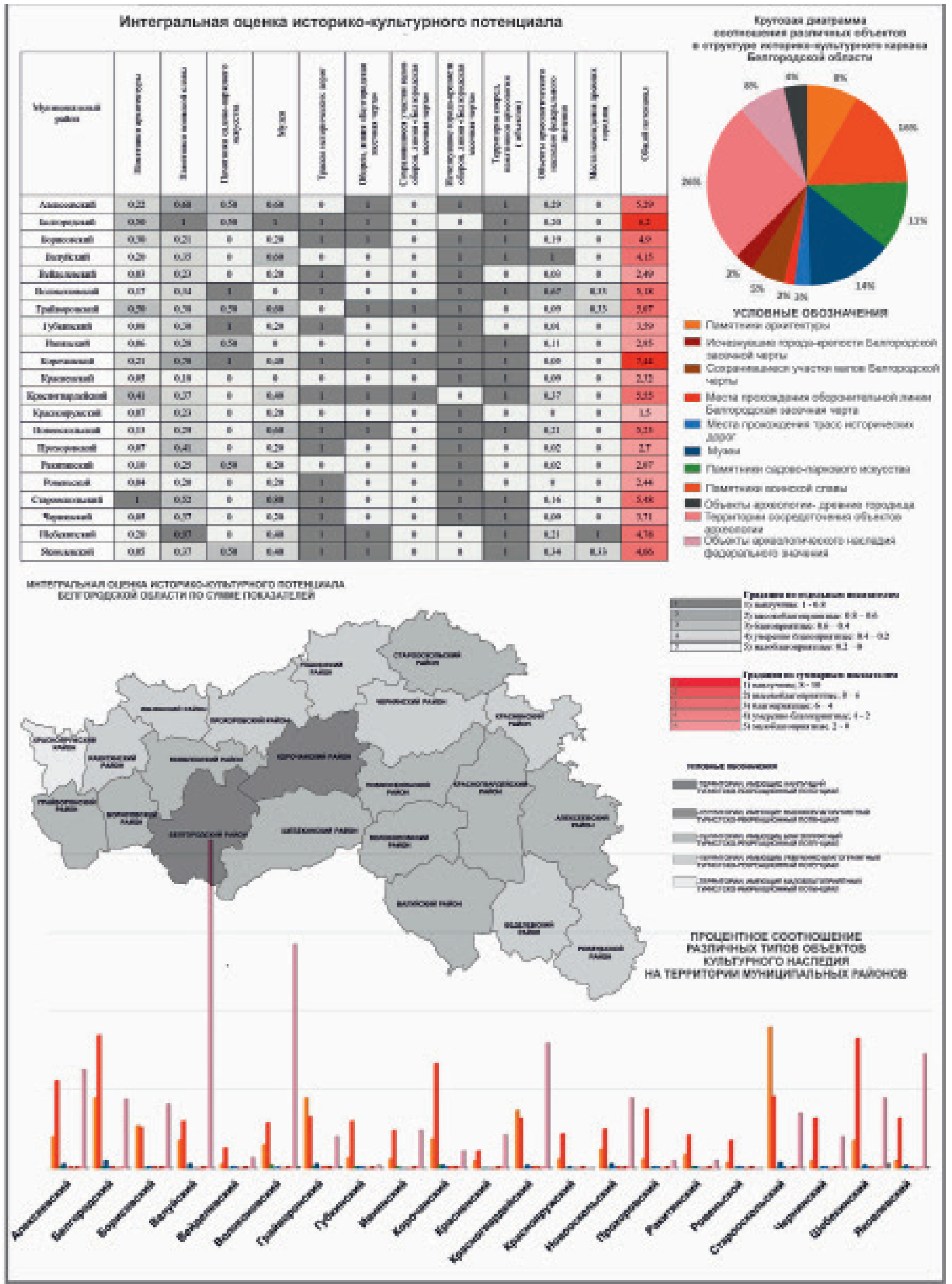

Рис. 2. Пример интегральной оценки и ранжирования муниципальных районов Белгородской области. Историко-культурный потенциал [5]. Разработчики схемы: Е.И. Ладик, М.В. Перькова 
высокой плотности; хорошая доступность центрального места отмечается в Корочанском, Шебекинском и Яковлевском районах;

5) социальная инфраструктура для жителей прилегающих сельских поселений сосредоточена в четырёх городах из
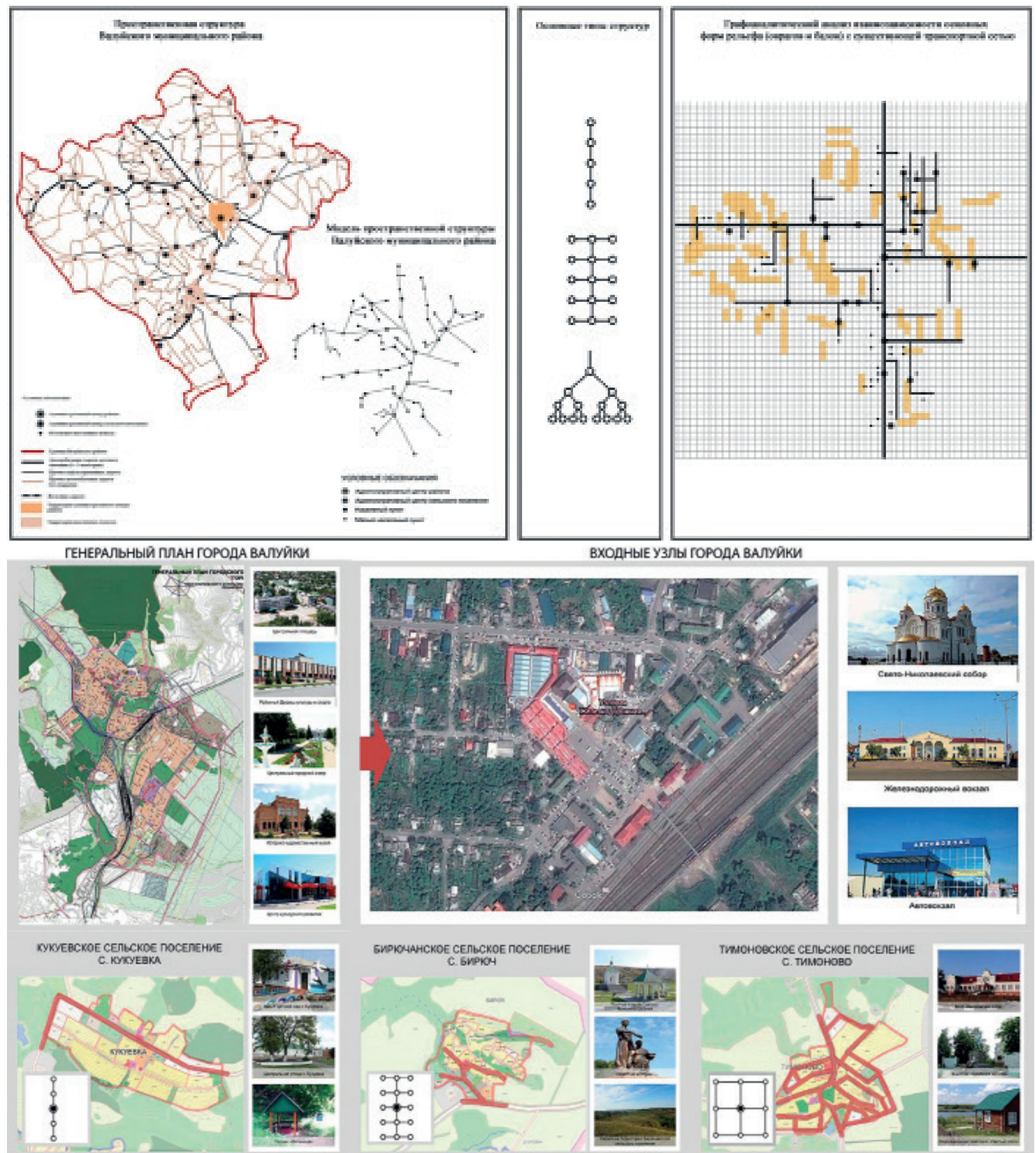

восьми рассматриваемых (Шебекино, Новый Оскол, Валуйки и Алексеевка).

${ }^{2}$ Байрачные леса - широколиственные леса, растущие по дну и склонам балок (байраков).
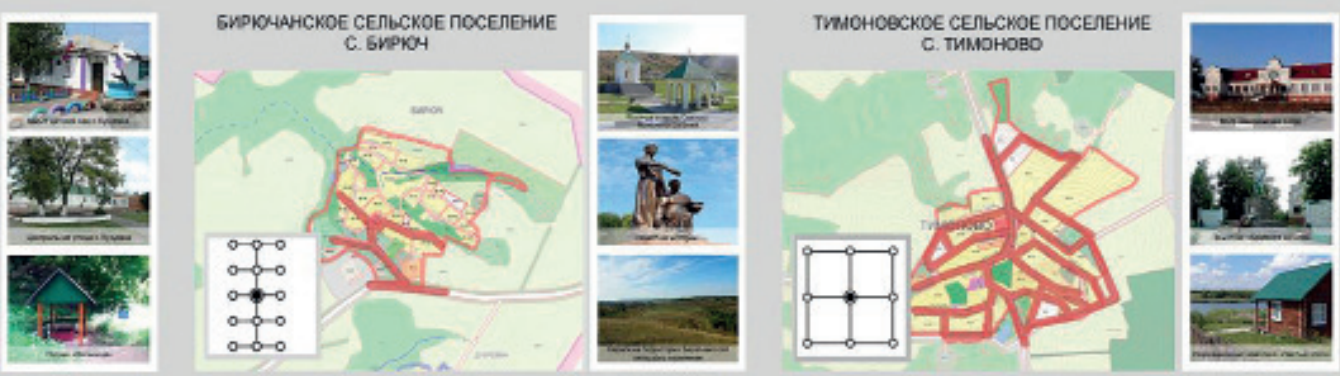

Рис. 3. Сетевые модели транспортной инфраструктуры Валуйского муниципального района. Разработчики схемы: М.В. Перькова, К.М. Трибунцева 
Далее были построены сетевые модели транспортной сети муниципальных районов для изучения различных видов пространственных отношений между элементами на основе исследований М.В. Шубенкова [14]. Они характеризуют связ-

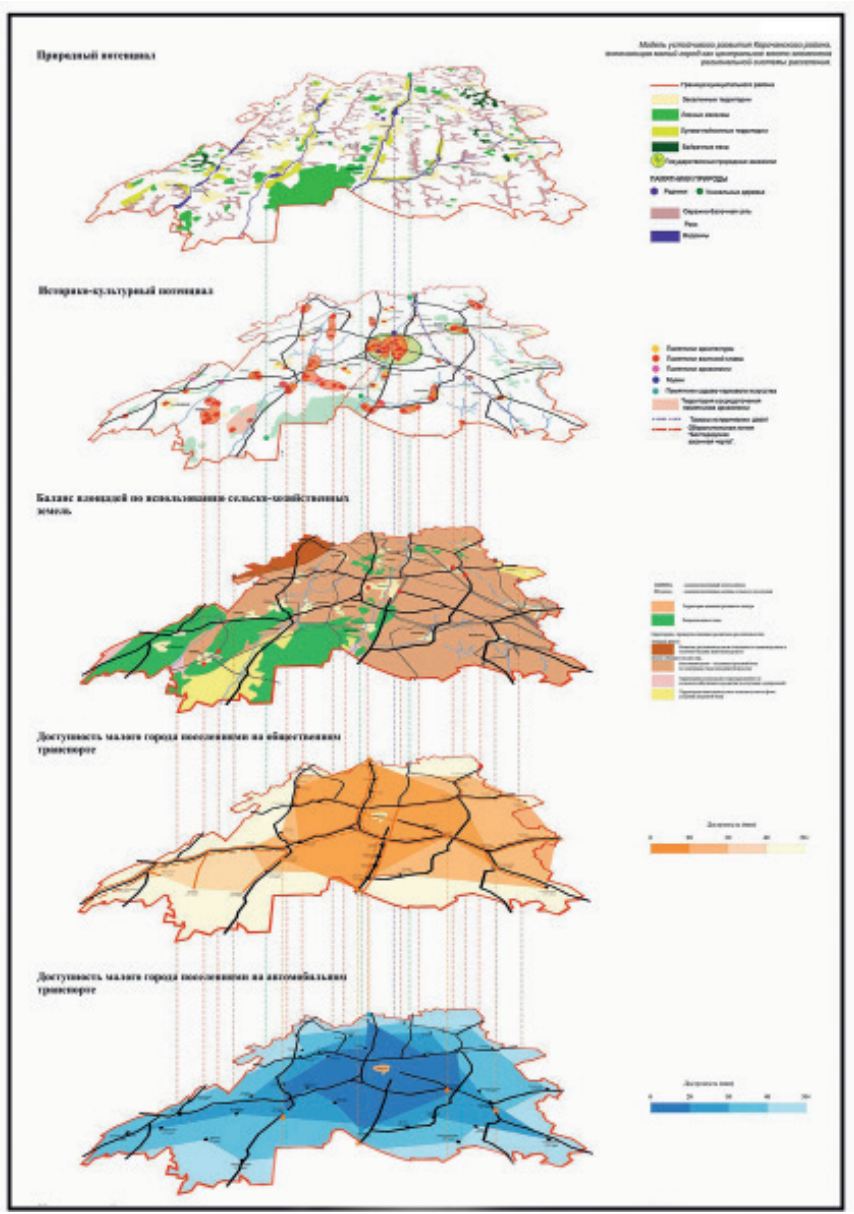

Рис. 4. Пример картографических моделей ресурсного потенциала Корочанского муниципального района Белгородской области

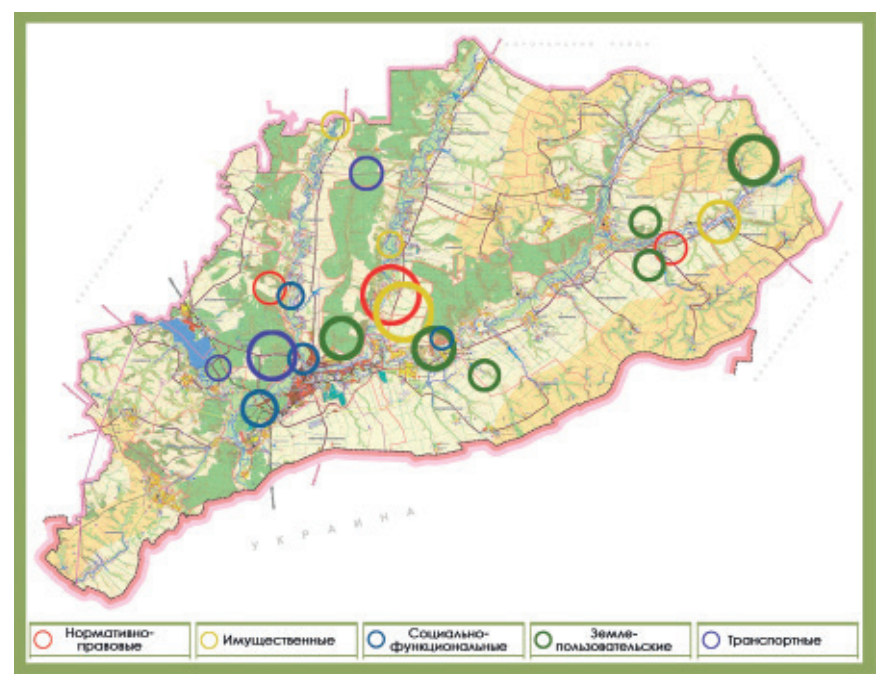

Рис. 5. Пример карты-схемы выявления градостроительных конфликтов интересов и ценностей участников градостроительной деятельности в Шебекинском районе Белгородской области и их классификации ность, дискретность и интеграцию межпространственных взаимодействий элементов региональной системы расселения:

1) координацию, или взаимная зависимость населённых пунктов;

2) детерминацию, или односторонняя зависимость;

3) констелляцию, или взаимная независимость (рис. 3).

На третьем этапе были разработаны картографические модели ресурсного потенциала муниципальных районов. При наложении моделей в местах пересечения интересов выявлены и классифицированы градостроительные конфликты на муниципальном уровне (рис. 4).

В результате исследования выявлено, что наиболее типичными для всех муниципальных районов являются следующие градостроительные конфликты:

1) землепользовательские, нормативно-правовые и социально-функциональные, связанные с освоением приречных территорий;

2) нормативно-правовые, связанные с сохранением историко-культурного наследия;

3) землепользовательские и социально-функциональные конфликты, связанные с функционированием агропромышленных холдингов (рис. 5).

Выявлены градостроительные противоречия развития территории муниципальных районов Белгородской области, например:

1) «экономико-экологическое противоречие» заключается в инновационном развитии агропромышленного комплекса и деградации земель [включает технологическую (эксплуатационную), физическую (земледельческую) деградации и агроистощение чернозёмных почв]. Характерно для всех муниципальных районов;

2) «пространственно-структурное противоречие» - плотность населённых пунктов и частично замкнутая сеть дорог, плохая транспортная доступность центрального места (малого города) на общественном транспорте. Характерно для Красногвардейского, Алексеевского и юго-западной части Яковлевского района.

3) «функционально-временное противоречие» - центрами притяжения для развития человеческого потенциала прилегающих сельских поселений является 50\% малых городов. Это связано с тем, что малый город как центр расселения не является привлекательным, так как не удовлетворяет потребности современного потребителя либо ближайшим центром притяжения является малый город соседнего района, а не того, к которому согласно административному делению принадлежит данное сельское поселение, так как до него дорога занимает большее количество времени;

4) «фискально-пользовательское противоречие» - «потеря» Губкинским муниципальным районом налогов от ГоКа (в пользу Липецкой области) без снижения нагрузки на природный каркас, транспортные и обслуживающие сети.

Для разрешения градостроительных конфликтов и противоречий развития на уровне муниципального района 
на четвёртом этапе исследования предложены усовершенствованные методы, которые апробированы на территориях Белгородского, Шебекинского муниципальных районах:

1) метод разрешения социально-инфраструктурных противоречий развития территории применён с целью развития социальной инфраструктуры кластерного типа в Белгородской агломерации для формирующихся микрорайонов индивидуальной жилой застройки;

2) метод формирования восстановительного рельефа нарушенных территорий. Использован на примере нарушенных территорий Белгородского и Шебекинского районов (отработанные песчаные и меловые карьеры). Предлагается облесение, регенерация почвенного покрова путём подсева типичных луговых растений лесостепной зоны и обводнение на основе имеющихся грунтовых вод;

3) метод формирования природного ядра на основе овражно-балочных ландшафтов. Включает облесение кромки оврага, обводнение днища оврага на основе имеющихся родников, экологическое зонирование овражного комплекса с дифференциацией в высотном направлении по уровням рекреационной нагрузки на нарушенных территориях в Белгороде.

Разработан метод гармонизации интересов и ценностей между участниками градостроительной деятельности путём поиска компромисса между ними в отношении территорий с различной функциональной нагрузкой, который апробирован на примере разработки концепции градостроительного развития межмуниципального природного парка на территории Белгородского и Шебекинского районов. Метод включает разрешение противоречий между интересами собственников и воссозданием природного каркаса, регенерации нарушенных территории, установление различных режимов освоения и уровня рекреационной нагрузки, а также предложения по организации рабочих мест нового технологического уклада.

\section{Лuтература}

1. Административно-территориальное деление Белгородского края. Конец XVI - начало XXI вв.: справочник / Сост. Л.В. Горбачева, Е.В. Кривцова, А.А. Кривчиков и др. - Белгород, 2011. - 536 c.

2. Большаков, А.Г. Градостроительная организация ландшафта как фактор устойчивого развития территорий: дис. ... д.-ра арх.: 18.00.01 / Большаков Андрей Геннадьевич. Иркутск, 2003. - 489 с.

3. Есаулов, Г.В. Архитектурно-градостроительное наследие Юга России: его формирование и культурный потенциал: автореферат дис. ... доктора архитектуры: 18.00.01 / Науч.исслед. ин-т теории архитектуры и градостр-ва. - Москва, 2004. - 57c.

4. Есаулов, Г.В. Концепция устойчивого развития в стратегии градостроительной модернизации России / Г.В. Есаулов, Д.Ю. Ломакина // Градостроительство. - 2011. - № 1. - С. 8-11.
5. Ладик, Е.И. Региональные особенности архитектурнопланировочной структурытуристско-рекреационныхтерриторий Белгородской области: диссертация ... кандидата архитектуры: 05.23.22 / Ладик Елена Игоревна; [Место защиты: С.-Петерб. гос. архитектур.-строит. ун-т]. - Белгород, 2017. - 167 с.

6. Лебединская, Г.А. О месте стратегии пространственного развития в системе территориального планирования Российской Федерации / Г.А. Лебединская // Academia. Архитектура и строительство. - 2018. - № 1. - С. 59-67.

7. Митягин, С.Д. Технологическая оптимизация градостроительной деятельности / С.Д. Митягин // Academia. Архитектура и строительство. 2018 - № 1. - С. 59-67.

8. Моисеев, Ю.М. Пороги неопределённости в системе градостроительного планирования: автореферат дис. ... доктора архитектуры: 05.23.22 / Моисеев Юрий Михайлович; Моск. архитектур. ин-т. - М., 2017. - 48 с. - С. 33-36.

9. Перькова М.В. Градостроительное развитие Белгородской региональной системы расселения и ее элементов / М.В. Перькова // Архитектура и строительство России. - 2016. Вып. 4. - С. 12-17.

10. Перькова, М.В. Исторический процесс формирования региональной системы расселения на территории Белгородской области/ М.В. Перькова // Вестник БГтУ им. Шухова. - 2017. - № 12. - С. 103-109.

11. Перькова, М.В. Методика выявления и разрешения градостроительных противоречий развития на региональном уровне / М.В. Перькова // Вестник БГТУ им. Шухова. - 2018. - № 4. - С. 62-72.

12. Схема территориального планирования Белгородской области/ Вып. по Гос. контракту № 1-ГК/06 от 25 мая 2006 г.

13. Хомяков, Д.А. Основы градостроительной стратегии развития загородных поселений Московского региона : автореферат дис. ... кандидата архитектуры: 05.23.22 / Хомяков Дмитрий Александрович; Моск. архитектур. ин-т. - М., 2018. - 34 с.

14. Шубенков, М.В. Структура архитектурного пространства / М.В. Шубенков // автореф. дис. д-ра арх.: 18.00.01 / Шубенков Михаил Валерьевич. - М., 2006. - 57с.

15. Чернова, E.Б. Социологическое обоснование стратегий территориального развития: методологические и практические аспекты / Е.Б. Чернова // Региональная экономика. Юг России. - 2017. - № 1 (15). - С. 36-46.

16. Чернова, Е.Б. Как снять противоречие социальных и экономических целей при разработке стратегий территориального развития (часть 2) [Электронный ресурс] / Е.Б. Чернова // ESTP. Экспертный строительный портал. - Режим доступа: http://estp-blog.ru/rubrics/rid-6069/ (дата обращения: 30.10.2014).

\section{Literatura}

1. Administrativno-territorial'noe delenie Belgorodskogo kraya. Konets XVI - nachalo XXI vv.: spravochnik / Sost. L.V. Gorbacheva, E.V. Krivtsova, A.A. Krivchikov i dr. - Belgorod, 2011. - 536 s. 
2. Bol'shakov A.G. Gradostroitel'naya organizatsiya landshafta kak faktor ustojchivogo razvitiya territorij: dis. ... d.-ra arh.: 18.00.01 / Bol'shakov Andrej Gennad'evich. - Irkutsk, 2003. - $489 \mathrm{~s}$.

3. Esaulov G.V. Arhitekturno-gradostroitel'noe nasledie Yuga Rossii : ego formirovanie i kul'turnyj potentsial: avtoreferat dis. ... doktora arhitektury: 18.00.01 / Nauch.-issled. in-t teorii arhitektury i gradostr-va. - Moskva, 2004. - 57s.

4. Esaulov G.V. Kontseptsiya ustojchivogo razvitiya v strategii gradostroitel'noj modernizatsii Rossii / G.V. Esaulov, D.Yu. Lomakina // Gradostroitel'stvo. - 2011. - № 1. - S. 8-11.

5. Ladik, E.I. Regional'nye osobennosti arhitekturnoplanirovochnoj struktury turistsko-rekreatsionnyh territorij Belgorodskoj oblasti: dissertatsiya... kandidata arhitektury: 05.23.22 / Ladik Elena Igorevna; [Mesto zashhity: S. - Peterb. gos. arhitektur.-stroit. un-t]. - Belgorod, 2017. - $167 \mathrm{~s}$.

6. Lebedinskaya G.A. 0 meste strategii prostranstvennogo razvitiya $v$ sisteme territorial'nogo planirovaniya Rossijskoj Federatsii / G.A. Lebedinskaya // Academia. Arhitektura i stroitel'stvo. - 2018. - № 1. - S. 59-67.

7. Mityagin S.D. Tehnologicheskaya optimizatsiya gradostroitel'noj deyatel'nosti / S.D. Mityagin // Academia. Arhitektura i stroitel'stvo. 2018 - № 1. - S. 59-67.

8. Moiseev Yu.M. Porogi neopredelennosti v sisteme gradostroitel'nogo planirovaniya: avtoreferat dis. ... doktora arhitektury: 05.23.22 / Moiseev Yurij Mihajlovich; Mosk. arhitektur. in-t. - M., 2017. - 48 s. - S. 33-36.

9. Per'kova M.V. Gradostroitel'noe razvitie Belgorodskoj regional'noj sistemy rasseleniya i ee elementov / M.V. Per'kova // Arhitektura i stroitel'stvo Rossii. - 2016. - Vyp. 4. - S. 12-17.
10. Per'kova M.V. Istoricheskij protsess formirovaniya regional'noj sistemy rasseleniya na territorii Belgorodskoj oblasti / M.V. Per'kova // Vestnik BGTU im. Shuhova. - 2017. - № 12. - S. 103-109.

11. Per'kova M.V. Metodika vyyavleniya i razresheniya gradostroitel'nyh protivorechij razvitiya na regional'nom urovne / M.V. Per'kova //Vestnik BGTU im. Shuhova. - 2018. - № 4. - S. 62-72.

12. Otchet o nauchno-issledovatel'skoj rabote na razrabotku «Skhemy territorial'nogo planirovaniya Belgorodskoj oblasti» (vypolnennoj po Gosudarstvennomu kontraktu № 1-GK/06 ot 25 maya 2006 g. s Upravleniem arhitektury i gradostroitel'stva administratsii Belgorodskoj oblasti).

13. Homyakov D.A. Osnovy gradostroitel'noj strategii razvitiya zagorodnyh poselenij Moskovskogo regiona : avtoreferat dis.... kandidata arhitektury: 05.23.22 / Homyakov Dmitrij Aleksandrovich; Mosk. arhitektur. in-t. - M., 2018. - 34 s.

14. Shubenkov M.V. Struktura arhitekturnogo prostranstva / M.V. Shubenkov // avtoref. dis. d-ra arh.: 18.00.01 / Shubenkov Mihail Valer'evich. - M., 2006. - 57s.

15. Chernova E.B. Sotsiologicheskoe obosnovanie strategij territorial'nogo razvitiya: metodologicheskie i prakticheskie aspekty / E.B. Chernova // Regional'naya ekonomika. YUg Rossii. - 2017. - № 1 (15). - S. 36-46.

16. Chernova E.B. Kak snyat' protivorechie sotsial'nyh i ekonomicheskih tselej pri razrabotke strategij territorial'nogo razvitiya (chast' 2) [Elektronnyj resurs] / E.B. Chernova // ESTP. Ekspertnyj stroitel'nyj portal. - Rezhim dostupa: http://estpblog.ru/rubrics/rid-6069/ (data obrashheniya: 30.10.2014).

Перькова Маргарита Викторовна (Белгород). Кандидат архитектуры, доцент. Заведующая кафедрой «Архитектура и градостроительство» ФГБОУ В0 «Белгородский государственный технологический университет им. В. Г. Шухова» (308012, Белгород, ул. Костюкова, 46. БГТУ им. В.Г. Шухова); докторант ФГБОУ В0 «СПбГАСУ» по научной специальности 05.23.22. Сфера научных интересов: градостроительство, градостроительное развитие региональных систем расселения, историко-культурное и природное своеобразие муниципальных районов и малых городов Белгородской области и их перспективное развитие. Автор более 70 научных публикаций, в т.ч. 4 монографии, 3 учебных пособия. Тел. 8 (4722) 30-99-83. E-mail: perkova.margo@mail.ru.

Perkova Margarita Viktorovna (Belgorod). Candidate of Architecture, Associate Professor. Head of the Department of Architecture and Urban Planning of Belgorod State Technological University named after V.G.Shukhov (308012, Belgorod, Kostyukov str., 46. BSTU); Doctoral candidate of the SPbGASU in scientific specialty 05.23.22. Sphere of scientific interests: urban planning, urban planning development of regional settlement systems, historical, cultural and natural originality of municipalities and small cities of the Belgorod region and their perspective development. The author of more than 70 scientific publications, including 4 monographs, 3 textbooks. Tel.+7 (4722) 30-99-83 E-mail: perkova.margo@mail.ru. 